\title{
PERBAIKAN BEBAN KERJA PEGAWAI TIDAK TETAP BADAN PERTANAHAN NASIONAL MELALUI REDESIGN SYSTEM
}

\author{
Meri Andriani $^{* 1}$, Muhammad Thaib Hasan ${ }^{2}$, Sondy Fradila ${ }^{3}$ \\ ${ }^{1,2,3}$ Prodi Industri, Universitas Samudra. (0641) 7445160 \\ e-mail: *11 meri_zulham@yahoo.com
}

\begin{abstract}
National Defence Agency is a Non-Ministerial Government Institution is which under and responsible to President and headed by a Chief. Land Agency produces products that prioritize on quality and legacy of law. Human resources have a major role in every company's activities. Although supported by facilities and infrastructure and excessive resources, but without the support of reliable resources, activities in an agency / company will not be resolved properly. Workload is a situation where workers are faced with tasks that must be completed at a certain time. The Problems in this research is the amount of workload for the employees both mentally and physically is too much that making mistakes and fatigue in working. The study aims to redesign the system in overcoming the workload experienced by the giving survey to the workers at the Land Agency at Langsa City.The method used is workload objectively by measuring the mental workload through the pulse, the questionnaire to know the amount of workload that affects work stress. The result of the research showed that the increase of pulse before working to the pulse after work, the average increase of the pulse of 47,9 beats / minute. Kasdiovasculer expense (\% CVL) employees claimed to require repair work system with the highest CVL\% is worth 55.24 beats / minute. The overrated of workload can cause work stress with the results obtained 0.9000>0.549 the employees have stress when the workload is excessively.
\end{abstract}

Keywords : Cardiovascular, Workload, Stress work.

\section{PENDAHULUAN}

Sumber daya manusia mempunyai peran utama dalam setiap kegiatan perusahaan. Walaupun didukung sarana dan prasarana serta sumber daya yang berlebihan, tetapi tampa dukungan sumber daya yang handal, kegiatan dalam sebuah instansi/perusahaan tidak akan terselesaikan dengan baik (Muhammad, 2016). Beban kerja (Workload) adalah keadaan dimana pekerja dihadapkan pada tugas yang harus diselesaikan pada waktu tertentu (Runtuwene, 2016). Beban kerja dari sudut pandang ergonomi yang diterima oleh seseorang harus sesuai atau seimbang baik terhadap kemampuan fisik, kemampuan kognitif, maupun keterbatasan manusia yang menerima beban tersebut (Andriani, 2015). Selama menjalankan aktivitas kerja, manusia mengalami dua jenis beban kerja yaitu beban kerja fisik dan beban kerja mental. Beban kerja fisik menunjukkan seberapa banyak aktivitas fisik yang dilakukan manusia selama bekerja, seperti mendorong, menarik, mengangkat, dan menurunkan beban. Sedangkan beban kerja mental merupakan kebutuhan mental seseorang seperti memikirkan, menghitungkan, dan memperkirakan sesuatu (Diniaty, 2016). Secara umum hubungan antara beban kerja dan kapasitas kerja dipengaruhi oleh berbagai faktor yang sangat kompleks, baik faktor internal maupun faktor eksternal. Faktor eksternal beban kerja adalah beban kerja yang berasal dari luar tubuh pekerja. Yang termasuk beban kerja eksternal adalah 
tugas (task) itu sendiri, organisasi dan lingkungan kerja. Kategori lain dari beban kerja adalah kombinasi dari beban kerja kuantitatif dan kualitatif. Beban kerja secara kuantitatif yang timbul karena tugas-tugas terlalu banyak atau sedikit, sedangkan beban kerja kualitatif jika pekerja merasa tidak mampu melakukan tugas atau tugas tidak menggunakan keterampilan atau potensi dari pekerjaan. Beban kerja fisikal atau mental yang harus melakukan terlalu banyak hal, merupakan kemungkinan sumber stres pekerjaan (Tarwaka, 2004). Tenaga kerja adalah setiap orang yang mampu melakukan pekerjaan guna menghasilkan barang dan/ atau jasa baik untuk memenuhi kebutuhan sendiri maupun untuk masyarakat (UU Ketenagakerjaan, 2003).Tenaga kerja yang baik, dapat melakukan pekerjaan yang telah diberikan kepadanya dengan efektif dan efisien. Hasil penelitian Anggraeni, dkk 2015 dengan judul “ Analisis Beban Kerja Untuk Menentukan Jumlah karyawan optimal" menyatakan bahwa kebutuhan sumber daya manusia (SDM) semakin meningkat baik dari segi kualitas maupun kuantitas. Pengukuran beban kerja diperlukan untuk menetapkan waktu bagi seorang karyawan yang memenuhi persyaratan dalam menjalankan pekerjaan tertentu pada tingkat prestasi yang telah ditetapkan. Untuk mengatasi masalah pengukuran beban kerja pada PT. Sanjayatama Lestari, maka dalam penelitian ini menggunakan metode Analisis beban Kerja. Metode ini akan memberikan informasi mengenai pengalokasian sumber daya manusia karyawan untuk menyelesaikan beban kerja yang ada. Berdasarkan hasil pengukuran beban kerja pada PT. Sanjayatama Lestari dengan menggunakan metode Analisis Beban Kerja dapat disimpulkan bahwa rata-rata beban kerja karyawan pada bagian Tabulator adalah 8650,866 jam /tahun jumlah karyawan.

\section{METODE PENELITIAN}

2.1. Tempat dan Waktu Penelitian

Penelitian dilakukan di Kantor Badan Pertanahan Kota Langsa, yang terletak di Jl. Prof. A.Majid Ibrahim No.6 Matang Seulimeng Langsa. Penelitian dilakukan mulai tanggal 01 Januari 2016 sampai dengan 01 Februari 2016.

2.2. Objek Penelitian

Objek penelitian yang diamati adalah Pegawai Tidak Tetap pada Kantor Badan Pertanahan Nasional Kota Langsa. Penelitian yang dilakukan jenis penelitian deskriptif yaitu penelitian yang bertujuan membuat gambaran tentang keadaan secara objektif.

\subsection{Instrumen Penelitian}

Instrument penelitian yang dipergunakan adalah :

1. Kardiograf berfungsi untuk mengukur denyut nadi pegawai tidak tetap.

2. Stopwatch berfungsi untuk mengukur waktu kerja.

3. Kuesioner berfungsi untuk mengetahui keluhan beban kerja pegawai tidak tetap.

4. Notes berfungsi untuk mencatat hasil wawancara yang berkaitan dengan perusahaan.

\subsection{Prosedur Pelaksanaan Penelitian}

Pelaksanaan penelitian memiliki prosedur sebagai berikut :

1. Melakukan observasi ke perusahaan dan wawancara kepada pegawai tidak tetap yang menjadi objek penelitian.

2. Identifikasi masalah untuk mengetahui besarnya beban kerja yang dapat menyebabkan stress kerja

3. Perumusan masalah didapat keluhan pegawai tidak tetap terhadap beban kerja yang mereka terima dan dapat menentukan tujuan penelitian. 
4. Pengumpulan data dilakukan untuk data denyut nadi, data waktu kerja dan kuesioner dari pegawai tidak tetap sebagai responden.

5. Pengolahan data dilakukan untuk mengetahui beban kardiovascular (\%CVL), konsumsi energi dan uji validitas dari kuesioner.

6. Kesimpulan dilakukan untuk menjawab hasil dari tujuan penelitian.

\section{HASIL DAN PEMBAHASAN}

\subsection{Beban Kardiovascular (\% CVL)}

Pengukuran denyut nadi dilakukan pada saat karyawan belum bekerja, pengukuran denyut nadi sebelum bekerja dinamakan Denyut nadi Istirahat (DNI) dan pengukuran denyut nadi pada saat melakukan pekerjaan disebut Denyut Nadi Kerja (DNK). Data DNI dan DNK terdapat pada gambar 1 .

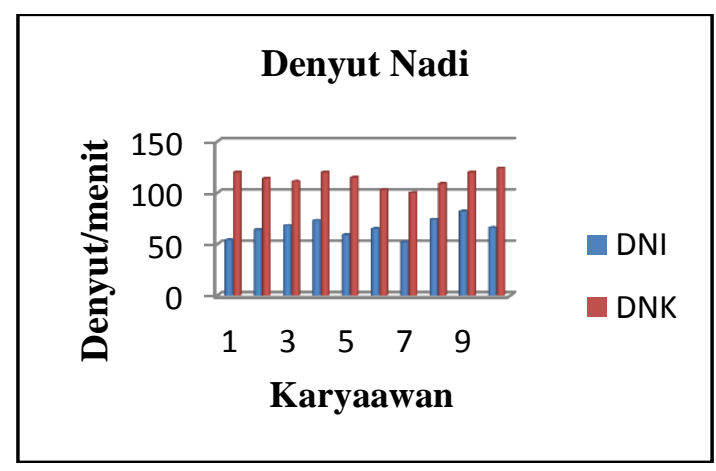

Gambar 1. DNI dan DNK

Gambar 1 membuktikan bahwa terjadi peningkatan denyut nadi sebelum bekerja ke denyut nadi setelah melakukan pekerjaan, rata-rata denyut nadi istirahat sebesar 65,7 denyut/menit, dan rata-rata denyut nadi kerja sebesar 113,6 pulse/menit.

Cardiovascular (\%CVL) merupakan yang didapat dari hasil pengolahan data denyut nadi terdapat pada gambar 2 .

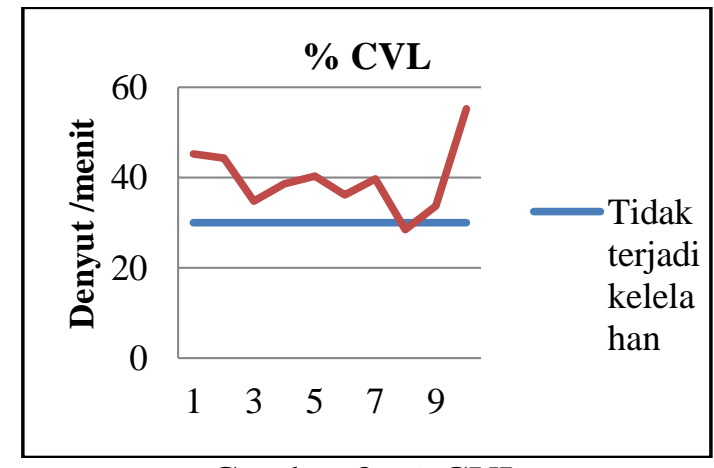

Gambar 2. \% CVL

Gambar 2 membuktikan bahwa hampir semua pegawai mengalami beban kerja yang berlebihan dan hanya satu pegawai yang tidak mengalami berlebihan beban kerja.

\subsection{Konsumsi Energi}

Metode konsumsi energi dilakukan dengan mendapatkan data dari denyut nadi. Rekapitulasi konsumsi energi terdapat pada gambar 3 .

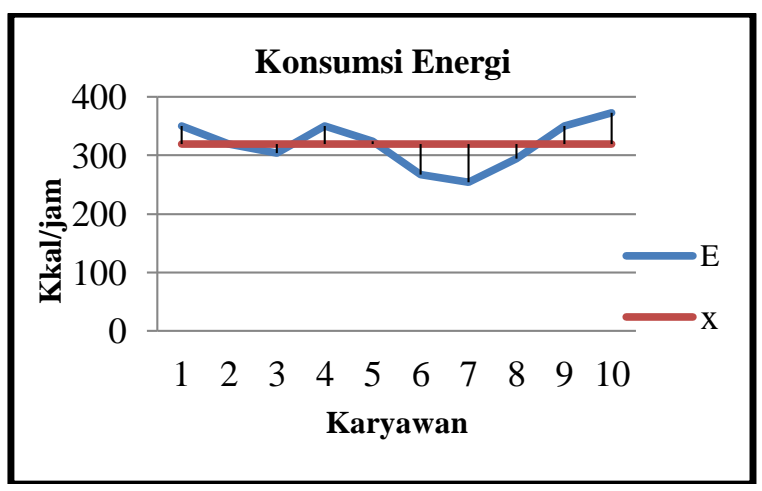

Gambar 3. Konsumsi Energi

Gambar 4 menyatakan bahwa konsumsi energi rata-rata masih berkategori sedang, dan empat karyawan yang berkategori berat.

\subsection{Kuesioner Beban Kerja}

Kuesioner dilakukan untuk melihat besarnya beban kerja yang dialami setiap karyawan. Kuesioner yang diberikan kepada pegawai tidak tetap yang terdiri dari delapan pertanyaan dengan bobot nilai

a. Sangat tidak setuju (sts) nilai 1 
b. Setuju (s)

nilai 2

c. Kurang setuju (ks)

nilai 3

d. Tidak setuju (ts)

nilai 4

e. Sangat tidak setuju (sts)

nilai 5

Rekapitulasi hasil kuesioner terdapat pada tabel 1.

Tabel 1. Hasil kuesioner

\begin{tabular}{|c|c|c|c|c|c|c|c|c|}
\hline & 1 & 2 & 3 & 4 & 5 & 6 & 7 & 8 \\
\hline sts & 0 & 0 & 0 & 0 & 0 & 0 & 0 & 0 \\
\hline ts & 0 & 0 & 1 & 0 & 0 & 0 & 0 & 0 \\
\hline ks & 1 & 1 & 0 & 0 & 0 & 1 & 0 & 2 \\
\hline s & 2 & 9 & 6 & 2 & 1 & 7 & 8 & 3 \\
\hline ss & 7 & 0 & 4 & 7 & 9 & 2 & 2 & 5 \\
\hline
\end{tabular}

Tabel 1 menunjukkan bahwa semua pegawai tidak tetap sangat setuju (ss) menyatakan bahwa beban kerja yang mereka terima besar.

\subsubsection{Uji Validitas Beban Kerja}

Uji validitas digunakan untuk mengetahui kelayakan butir-butir dalam suatu daftar pertanyaan. Rekapitulasi uji validitas terdapat pada Tabel 2.

Tabel 2. Rekapitulasi Uji Validitas

\begin{tabular}{|c|c|c|c|c|}
\hline No & Variabel beban kerja & $\begin{array}{l}\mathbf{r} \\
\text { tabel }\end{array}$ & $\begin{array}{l}\mathbf{r} \\
\text { hitung }\end{array}$ & ket. \\
\hline 1 & $\begin{array}{l}\text { Saya memiliki waktu } \\
\text { luang yang sedikit }\end{array}$ & 0,549 & 0,918 & valid \\
\hline 2 & $\begin{array}{l}\text { Saya sering kali } \\
\text { mendapatkan gangguan } \\
\text { selama } \\
\text { melakukan pekerjaan }\end{array}$ & 0,549 & 1,092 & valid \\
\hline 3 & $\begin{array}{l}\text { Saya sering kali } \\
\text { mengerjakan dua/ lebih } \\
\text { pekerjaan } \\
\text { dalam waktu yang } \\
\text { bersamaan }\end{array}$ & 0,549 & 1,695 & valid \\
\hline 4 & $\begin{array}{l}\text { Saya membutuhkan } \\
\text { konsentrasi tinggi dalam } \\
\text { menyelesaikan pekerjaan }\end{array}$ & 0,549 & 1,396 & valid \\
\hline 5 & $\begin{array}{l}\text { Pekerjaan yang saya } \\
\text { lakukan tidak menentu } \\
\text { datangnya }\end{array}$ & 0,549 & 1,247 & valid \\
\hline 6 & $\begin{array}{l}\text { Pekerjaan saya memiliki } \\
\text { tingkat resiko yang tinggi }\end{array}$ & 0,549 & 1,505 & valid \\
\hline 7 & $\begin{array}{l}\text { Saya merasa bingung dan } \\
\text { gelisah jika mengerjakan }\end{array}$ & 0,549 & 1,465 & valid \\
\hline
\end{tabular}

pekerjaan yang tidak

sesuai dengan latar

belakang

pendidikan saya

8 Saya merasa tingkat

kompensasi yang saya

dapat

saat ini dapat mengurangi

tekanan pekerjaan saya

Tabel 2 menunjukkan Tabel 2 menyatakan bahwa nilai rata-rata $r$ hitung untuk pertanyaan adalah 1,369 dengan tingkat signifikan adalah 0,9877 dibandingkan dengan nilai $\mathrm{r}$ tabel untuk taraf kesalahan $5 \%$ yaitu sebesar 0,549. karena nilai $r$ hitung > nilai $\mathrm{r}$ tabel yaitu $0,9877>0,549$ maka pertanyaan tersebut valid.

Pengukuran stres kerja dilakukan untuk mengetahui pengaruh beban kerja terhadap stress kerja. Data dimaksudkan untuk memberikan gambaran bagaimana stres kerja pegawai tidak tetap. Kuesioner terdiri dari delapan pertanyaan, masing-masing pertanyaan berisikan 3 alternatif pilihan yaitu :
a. Tidak pernah (TP) nilai 1
b. Kadang kadang (KD) nilai 2
c. Sering (SR)
nilai 3

Rekapitulasi pengukuran stress kerja terdapat pada table 3 .

Tabel 3. Pengukuran Stress Kerja

\begin{tabular}{|c|c|c|c|c|c|c|c|c|}
\hline Alternatif & 1 & 2 & 3 & 4 & 5 & 6 & 7 & 8 \\
\hline TP & 3 & 1 & 1 & 0 & 1 & 0 & 1 & 2 \\
\hline KD & 1 & 5 & 2 & 5 & 4 & 4 & 5 & 4 \\
\hline SR & 6 & 4 & 7 & 5 & 5 & 6 & 4 & 4 \\
\hline
\end{tabular}

Tabel 3 menyatakan bahwa setiap karyawan sering (SR) mengalami stress kerja terutama pada pertanyaan 1, 3 dan 6 .

\subsubsection{Uji Validitas Stress Kerja}

Uji validitas digunakan untuk mengetahui kelayakan butir-butir dalam suatu daftar pertanyaan. Rekapitulasi uji validitas stress kerja terdapat pada tabel 4 . Tabel 4. Rekapitulasi Uji Validitas Strees

Kerja

\begin{tabular}{llccc}
\hline No & Variabel stres kerja & r tabel & r hitung & ket. \\
\hline 1 & $\begin{array}{l}\text { Saya tidak dapat } \\
\text { menenangkan diri }\end{array}$ & 0,549 & 0,875 & valid
\end{tabular}




\begin{tabular}{|c|c|c|c|c|}
\hline & $\begin{array}{l}\text { menghadapi pemohon } \\
\text { yang mengeluh }\end{array}$ & & & \\
\hline 2 & $\begin{array}{l}\text { Saya sering lembur } \\
\text { termasuk hari libur }\end{array}$ & 0,549 & 1,636 & valid \\
\hline 3 & $\begin{array}{l}\text { Saya tidak } \\
\text { memperhatikan kesehatan } \\
\text { pada saat sibuk. }\end{array}$ & 0,549 & 1,566 & valid \\
\hline 4 & $\begin{array}{l}\text { Saya merasa bersemangat } \\
\text { bekerja jika peserta yang }\end{array}$ & 0,549 & 1,642 & valid \\
\hline & datang sedikit jumlahnya. & & & \\
\hline 5 & $\begin{array}{l}\text { Saya merasa denyut } \\
\text { jantung kencang ketika }\end{array}$ & 0,549 & 1,710 & valid \\
\hline & $\begin{array}{l}\text { banyak peserta yang harus } \\
\text { dilayani. }\end{array}$ & & & \\
\hline 6 & $\begin{array}{l}\text { Jika sedang mengerjakan } \\
\text { pekerjaan/laporan, kepala } \\
\text { saya sering pusing. }\end{array}$ & 0,549 & 1,664 & valid \\
\hline 7 & $\begin{array}{l}\text { Otot punggung saya terasa } \\
\text { kaku setelah selesai } \\
\text { bekerja } \\
\text { menyelesaikan laporan di } \\
\text { depan komputer. }\end{array}$ & 0,549 & 1,636 & valid \\
\hline 8 & $\begin{array}{l}\text { Saya sering berfikir } \\
\text { mengganggu pekerja unit } \\
\text { lain setika selesai }\end{array}$ & 0,549 & 1,674 & Valid \\
\hline
\end{tabular}

Tabel 4 menyatakan hasil kuesioner nilai rata-rata $r$ hitung untuk pertanyaan diatas adalah 1,550 dengan tingkat signifikan 0,05 adalah 0,9000 dibandingkan dengan nilai $r$ tabel untuk taraf kesalahan $5 \%$ yaitu sebesar 0,549. karena nilai $r$ hitung $>$ nilai $\mathrm{r}$ tabel yaitu $0,9000>0,549$ maka pertanyaan tersebut valid.

\section{4. Design System}

Desygn System dilakukan untuk memperbaiki sistem kerja yang terjadi, sehingga beban kerja karyawan dapat berkurang dan juga meminimalkan stress kerja. Adapun design system terdapat pada tabel 5 .

Tabel 5. Design System

\begin{tabular}{|c|c|c|c|c|c|c|c|}
\hline \multicolumn{8}{|c|}{ Nama A } \\
\hline \multicolumn{2}{|c|}{ Nama Jabatan Staf: } & \multicolumn{2}{|c|}{ Administrasi SPP } & & & & \\
\hline $\mathrm{N}_{0}$ & Uraian Tugas & SH & BK & WP (menit) & SK (menit) & PYD & KET \\
\hline 1 & input berkas prona & Berkas & 600 & 7 & 6.000 & 0,700 & 5 orang \\
\hline 2 & cetak surat tugas pengukuran prona & Berkas & 600 & 7 & 6.000 & 0,700 & \\
\hline 3 & cetak SU prona & Berkas & 600 & 15 & 6.000 & 1,500 & \\
\hline 4 & validasi berkas prona & Berkas & 600 & 5 & 6.000 & 0,500 & \\
\hline 5 & Mencetak PBT Berkas Rutin & Berkas & 5 & 5 & 300 & 0,083 & \\
\hline 6 & Mencetak SU Berkas Rutin & Berkas & 5 & 5 & 300 & 0,083 & \\
\hline 7 & Mencetak GU Berkas Rutin & Berkas & 5 & 5 & 300 & 0,083 & \\
\hline \multirow[t]{2}{*}{8} & Merapikan Berkas Pemisahan & Kegiatan & 10 & 2 & 300 & 0,067 & \\
\hline & Sebelum naik ke Kasubsi pengukuran & & & & & & \\
\hline \multirow[t]{2}{*}{9} & Mengontrol Berkas Pendaftaran & Kegiatan & 3 & 1 & 300 & 0,01 & \\
\hline & Pertama Kali & & & & & & \\
\hline \multirow[t]{3}{*}{10} & Cetak Surat Tugas Pengukuran & Berkas & 5 & 10 & 300 & 0,167 & \\
\hline & untuk kegiatan Pendaftaran & & & & & & \\
\hline & Pertama Kali & & & & & & \\
\hline \multirow[t]{3}{*}{11} & Membantu Koordinator Unsur & Kegiatan & 5 & 60 & 300 & 1,000 & \\
\hline & dalam hal yang sifatnya teknis & & & & & & \\
\hline & \multicolumn{3}{|c|}{ Jumlah pegawai yang diperlukan } & & & 4,893 & \\
\hline
\end{tabular}

Keterangan kolom isi :

Uraian tugas : Tugas yang dilakukan staff. Satuan hasil $(\mathrm{SH})$ : Satuan hasil / output dari setiap.

Contoh satuan hasil : berkas, laporan, kegiatan, rencana.

Beban Kerja (BK) : Jumlah hasil / output dari setiap tugas.

Waktu Pengerjaan (WP) : Waktu yang dibutuhkan untuk menyelesaikan/melaksanakan (satu/sebuah) tugas dalam hitungan menit. Standar Kerja (SK) : Jenis waktu (harian : 300 menit, mingguan : 1.500 menit, bulanan : 6.000 menit, tahunan : 72.000 menit)

Pegawai Yang Diperlukan (PYD) : Jumlah beban (BK) dikalikan dengan waktu pengerjaan dibagi standar kerja (SK) kegiatan (BK x WP / SK).

Tabel 5 Dalam satu hari jumlah jam kerja pegawai adalah 7,5 jam dimana 2,5 jam digunakan untuk waktu istirahat.

Contoh " tugas operator computer dalam membuat catatan yang telah selesai dikoreksi"

Pembuatan catatan perkara yang telah selesai dikoreksi merupakan kegiatan harian ( $\mathrm{SH}=300$ menit), dalam 300 menit/ 1hari operator computer dapat mengkoreksi 2 berkas (BK=2) dimana waktu yang dibutuhkan untuk melakukan pengkoreksian 1 berkas membutuhkan 
waktu 10 menit (WP = 10 menit/berkas $)$, maka pengawai yang diperlukan untuk mengerjakan tugas tersebut adalah 0,067 pegawai $(\mathrm{PYD}=0,067)$.

\section{KESIMPULAN}

Berdasarkan pengolahan data dan analisis pemecahan masalah pada penelitian tugas akhir maka kesimpulan yang diperoleh sebagai berikut:

1. Terjadinya peningkatan denyut nadi sebelum bekerja ke denyut nadi setelah melakukan pekerjaan, rata-rata denyut nadi istirahat sebesar 65,7 denyut/menit, dan rata-rata denyut nadi kerja sebesar 113,6 denyut/menit sehingga rata-rata peningkatan denyut nadi sebesar

2. \% CVL yang diukur $90 \%$ menyatakan diperlukan perbaikan sistem kerja dengan \% CVL tertinggi bernilai 55,24 denyut/menit.

3. Beban kerja yang diberikan kepada pegawai tidak tetap dapat mempengaruhi stres kerja dengan hasil yang didapat $0,9000>0,549$ maka pertanyaan tersebut valid sehingga $\mathrm{H}_{0}$ diterima dimana pekerja mengalami stres ketika beban kerja berlebihan. dan Teknologi Terapan III. 225232.

Mikhael Yonatan Roring, dkk. 2014. Stress Kerja Dan Lingkungan Kerja Pengaruhnya Terhadap Prestasi Pegawai Pada Biro Umum Setda Provinsi Sulawesi Utara. Jurnal EMBA. Vol.2.

Nurlia Karim,. 2013. Stres Kerja Pengaruhnya Terhadap Prestasi Kerja Pada Karyawan Café Bambu Express Manado. Jurnal EMBA. Vol. 1.

Patricia Runtuwene, dkk. 2016. Pengaruh Penemapatan Kerja, Mutasi dan Beban Kerja Terhadap Kinerja Karyawan Pada PT. Bank Sulutgo Manado. Jurnal Berkala Ilmiah Efisiensi. Vol. 6.

Sri Rahayu Muhammad, dkk. 2016. Pengaruh Lingkungan Kerja, Kompensasi, dan Beban Kerja Terhadap Kinerja Karyawan Pada Dinas Pendapatan Daerah Kota Manado. Jurnal EMBA. Vol. 4.

Tarwaka, dkk. 2004. Ergonomi.Untuk Keselamatan, Kesehatan Kerja dan Produktivitas. UNIBA PRESS. Surakarta.

\section{DAFTAR PUSTAKA}

Andriani, Meri dan Dewiyana. 2015. Analisa Subyektifitas dan Beban Kerja Secara Ergonomi Untuk Meningkatkan Produktivitas. Langsa. Jurutera, Vol 02.

Dewi Diniaty, dkk. 2016, Analisis Beban Kerja Fisik dan Mental Karyawan Pada Lantai ProduksiDipt. Pesona Laut Kuning, Jurnal Sains, Teknologi dan Industri. Vol.13.

Linanda Eka Angraeni, dkk. 2015. Analisis Beban Kerja Untuk Menentukan Jumlah karyawan optimal. Seminar Nasional Sains 